\title{
A NEW TAKE ON THE ASSESSMENT OF FIRST-YEAR ART PROJECTS
}

\section{G. Westraadt}

Teacher Education, Unit for Literacy

Cape Peninsula University of Technology

Wellington, South Africa

e-mail: westraadtg@cput.ac.za

\section{ABSTRACT}

In a search for fresh forms of formative assessment that promotes student learning and encourage students to take responsibility for their own learning, a reflective study was conducted after two assessment instruments were applied in the evaluation of first-year B.Ed. students in Art Education. The first assessment was designed to assist students to overcome their apprehension about mark-making (drawing) and with the second, consideration was given to whether assessments prepared students for a lifetime of learning.

Many first-year students entering their teacher training have not done any art since primary school. As part of the B.Ed. course they are required to produce a practical portfolio where they apply the art elements. For some students, this is a daunting task because they have very little confidence in their own creative ability. As a strategy to overcome their initial fear of drawing, a River of Life (Fisher and White 2015) exercise was introduced to set off their practical work.

The theoretical component of the B.Ed. 1 course in Art Education comprises of a) the didactics of the subject and b) basic background knowledge of South African art and artists. A component of this work is assessed by means of a written test, but in the past the outcome was very poor. In an attempt to improve their lack of knowledge in this regard, instead of a written test, students were required to come to class with prepared notes and using that, had to design a flowchart as if in preparation for a slide show of a particular component of the work.

Some examples of the end results of the River of Life drawings were analysed and will be discussed to establish whether it could be considered a reliable instrument to assess the ability of B.Ed. 1 students in the practical application of the elements of art. Results of the flowcharts as part of the theory assessment have been analysed to ascertain whether it has been a reliable assessment tool for this particular component of their course, enabling students to source and apply knowledge about art and artists of South Africa.

Results of this research could suggest guidelines to forms of assessment other than the traditional, as reliable instruments in Art Education.

Keywords: Formative assessment, Art Education, practical work, theoretical component.

\section{INTRODUCTION}

Many first-year students entering their teacher training have not done any art since primary 
school. As part of the B.Ed. programme they are required to produce a practical portfolio where they apply the art elements for their compulsory Art Education course. For some students, this is a daunting task because they have very little confidence in their own creative ability.

Another part of their Art Education course requires from them to acquire some knowledge of the art and artists of their own country on a level that they can teach it to children in the primary school. There is also a component on didactics which many students don't consider as that important. This attitude has led to very poor/unsatisfactory results for their assessments in the past.

In a search for fresh forms of formative assessment that promotes student learning and would encourage students to take responsibility for their own learning, and lead to lifelong learning, a reflective study was conducted after two assessment instruments were applied in the evaluation of first-year BEd students in Art Education. The first assessment was designed to assist students to overcome their apprehension about mark-making (drawing) and with the second, consideration was given to whether assessments prepared students for a lifetime of learning.

\section{Literature review}

According to Dreyer $(2014,1)$ assessment is a judgement of performance measured against criteria. It is a process during which information is collected from a variety of sources to determine what students know, understand and can do with knowledge that was gained during their learning. Assessment results can be used to improve future learning.

For this article the literature on assessment in higher education will be cited, in particular formative assessment and assessment for learning. Literature on assessment of practical work in Art Education, as well as attention to the assessment of theory projects in Art Education will be cited. It has to be borne in mind that the assessment of Art Education will differ from the assessment of fine art portfolios and theory.

\section{Assessment in higher education}

In a search for fresh and innovative forms of assessment that promotes student learning and would encourage students to take responsibility for their own learning, the literature on assessment in higher education brought valuable insights.

For many lecturers administering assessment is about measuring existing knowledge and reporting on current learning without really promoting long-term learning (Quinn 2015, 2). According to Quinn $(2015,2)$ assessment in higher education has a great impact on student 
learning and it influences how students respond to their studies. Assessment signals to them what their lecturers regard as important and thus what they should pay attention to. Boud and Falchikov $(2007,3)$ point out that assessment has a powerful effect on what students do and how they do it. Assessment transfers messages of success or failure to students.

One of the aims of higher education is to facilitate the autonomy of students, leading to lifelong learning. Assessment, formative and summative, that leads to lifelong learning should be divergent and should encourage student self-regulation (Yorke 2003, 480). Lecturers should regard the role of assessment tasks as conducive to student development, providing them with the ability to come to ethical conclusions and act accordingly (Yorke 2003, 491).

Formative and summative assessment has an effect on assessors. Not only can the development of student capability be gauged, but after reflection, if required, adjustments of future teaching can be made (Yorke 2003, 482).

\section{Methods of assessment}

Multiple methods of assessment are engaged in higher education with combinations of quantitative and qualitative methods. Qualitative methods enable the observation of broader dimensions of learning, such as how students translate understanding into behaviours, dispositions, reactions and interactions (Maki 2007, 87).

There is a distinction made between formative assessment and summative assessment. However, some authors feel that the distinction between formative and summative assessment is vague (Yorke 2003, 479). Formative assessment is a way for the student to learn, as well as a way for a faculty to learn about the efficacy of the learning activities that form part of the curriculum. Summative assessment on the other hand, establishes evidence of the end of the extent to which the student has achieved curricular objectives (Yorke 2003, 479).

Formative assessment differs from summative assessment mainly in that it is dialogic, since the student receives feedback from the teacher and may have the opportunity to engage the teacher in discussion about the assessment. Whilst the validity of the assessment has to reach an acceptable level, the reliability is less important because the fundamental purpose of the activity is developmental rather than related to measurement. During the feedback between teacher and student both aim to understand the communication of the other with the purpose of equipping the student to deal with future challenges (Yorke 2003, 485).

Boud (2000, 19) advocates 'sustainable assessment', which focuses on the learning process and whether learning will continue after the assessment period. Sustainable assessment develops judgement, the ability in students to evaluate evidence, gauge conditions and 
situations wisely and to draw conclusions and act appropriately. This kind of learning is important for their future careers (Quinn 2015, 3).

\section{Assessment in Art Education}

In Art Education, there will be assessment of practical work but also of a theoretical component. The practical work comprises portfolios of two-dimensional or three-dimensional work. A practical portfolio acts as a database of what's been done and learnt. It is a valuable source of information. The theoretical work can include research assignments, essays and tests.

Practical work in Art Education aims to encourage creativity and expression. Indicators of success are found in the finished product. The process by which this final product is arrived at has to be considered for assessment. There is room for experimentation through drafts and designs and discussion of the process and material by which designs were made. Every student produces unique work which required inspiration and thoughtful processes. Open-ended tasks that encourage debate and dissent and the relevance of the process to reach the overall aim make Art Education a rich terrain for the assessment of learning (Black, Harrison, Lee, Marshall and William 2006, 69-71).

According to Maki $(2007,89)$ formative assessment methods are built into visual art by providing continuous feedback to students. In agreement with this statement, Andrade, Heffering and Palma (2014, 34), as part of the Artful Learning Communities project, experimented with the latest assessment techniques for Art Education in order to increase student engagement and learning. These researchers all emphasised how on-going, informal feedback to students deepens their understanding of concepts and skills (Andrade, Heffering and Palma 2014, 34). Successful assessment of art projects require dependable, creative methods by which goals and expectations are clearly articulated to students. Another recommendation is self- and peer-assessment after which projects can be amended. Selfassessment helps students become aware of shortfalls in their learning, whilst modification offers opportunities to close the gaps (Andrade, Heffering and Palma 2014, 35).

Andrade, Heffering and Palma (2014, 37) describe how for practical work, self- and peerassessment with the use of rubrics encourages students to carefully consider the quality of their work and to reflect on ways in which it could be improved. Students developed attributes that are most desirable for learners, including self-monitoring, self-assessing, and self-teaching.

When Brandt (1987, 30) questioned Howard Gardner about Project Zero for the assessment of art, some light was shed on the assessment of the art of generalist students. Gardner emphasises that it is a mistake to try and assess art the same as other subjects. Artistic 
thinking is a unique way of using the mind, representing distinctive cognitive skills. What's important in art is difficult to assess, namely the personal meaning and emotional content that the maker invests in practical work.

In most schools the arts play an important part in the Foundation Phase, but it vanishes around Grade 8. Many first-year students have not had quality artistic experiences during their school time. Discussing the assessment of all students' art, not only those who choose the subject as an elective, Gardner, in conversation with Brandt (1987), recommended that such students should, prior to assessment, be exposed to rich experiences and activities in art. They should be involved with creating artworks, but also in projects involving analysis, perceptual discrimination and reflection on what they have been doing. Immerse in activities that call for artistic thinking and after some experience, assess the work by the use of various techniques, some straightforward, others unobtrusive. Aesthetic growth is clear from production, perception and reflection. How do people learn to see? The centrality of production, linked with perception and reflection is paramount. Learning grows from doing. When perception improves, they learn to see better, make finer discriminations and see connections between things. When they reflect, they step back from the creation and consider revision and improvement (Brandt 1987, 30-34).

For the theoretical component, visual literacy and knowledge of the work of artists are important. This requires a critical and analytical study of artworks (Black et al. 2006, 69). Visual literacy studies explore the historical, cultural, and critical context from which visual art content derives. It embraces diverse cultural identities, the interdisciplinary character of knowledge and technology. As part of visual culture studies, ideas can be developed from themes using a variety of means including online resources, observations, library research and reading. Students can collect information; reflect on meanings and the richness of global cultures. The focus should be on the process of learning as they organize their knowledge. Electronic resources can shed light on contemporary discourse on post-modern art forms (Popovich 2006, 34-35).

\section{Assessment criteria}

Imagination is at the core of the art-making process. It is very difficult to assess creative thinking. To establish the ingenuity of an artwork requires the assessor to make certain judgements. Designing reliable assessment tasks and using portfolios based on holistic assessment criteria will lead to good practices in student assessment (Cohen 2015, 383).

The visual nature of art limits tightly-defined criteria. However, the following criteria can be agreed upon as indicative of quality in art: originality, conceptual content and technical 
competence. Qualities to look for pose multilayered and complex judgement. According to Bolton (2006, 66-73) assessment of art can be grouped into the following categories:

- $\quad$ There should be originality which demonstrates creativity or imagination.

- Technical competence led by an ability to manipulate the elements of art and art materials.

- $\quad$ The conceptual content whereby ideas and feelings are conveyed.

- $\quad$ The ability to criticise or make visual analyses of art.

- $\quad$ Pervading all of these is the criterion of aesthetic sensibility.

Assessment of art causes concerns for many educators because it is a complex issue to measure creativity. Some art teachers follow their own judgement when evaluating students' art. Often, methods and criteria for evaluating creativity vary and assessment criteria adopted are often arbitrary. According to Leong and Qui $(2013,598)$ assessment is important to gauge the success of the Art Education practice as well as the teaching and learning. Many assessment instruments are not designed to measure creativity and the appropriateness of the assessment instruments used. The impact of unsuitable assessment practices on creativity can harm the main purpose of educational engagement in art (Leong and Qui 2013, 599).

Stokrocki $(2005,20)$ has proposed the following assessment tools to be built into the everyday teaching of art: rubrics, observation procedures, portfolio reviews and performancebased assessments. While it is important for students to be evaluated, teachers should be mindful that learning should focus on improvement and progress, and they should allow students to make their own personal meanings, expressions, values and attitudes (Leong and Qui 2013, 611).

\section{River of Life}

River of Life is a visual narrative method that helps people tell stories of the past, present and future. Individuals can use this method to introduce themselves in a fun and descriptive way; a group can use it to understand and reflect on the past and imagine the future of a project. River of Life focuses on drawing rather than text, making it useful in groups that do not share a language (Fisher and White 2015).

Morris (2015, 2) describes how, using simple sketches, students can explore meaningful events and turning points in their life stories. It is a reflective process with the use of creative and artistic activities that integrate several mental processes. 'Draw My Life' stories gather cognitive and emotional information from the visual, auditory, kinaesthetic, and memories. 
Connections and causal factors are found and the process involves an internal dialogue and reflection (Morris 2015, 2).

Our most powerful autobiographical memories almost always come with vivid visual images. Visual imagery is closely linked to reliving, a metacognitive property of autobiographical memory. Behavioural and neurological evidence suggests that visual imagery and autobiographical memory are closely intertwined. When we retrieve an autobiographical memory, visual imagery plays a fundamental role. Autobiographical memory is a complex cognitive process that draws on many other processes. Autobiographical knowledge can be divided into three levels of specificity: lifetime periods, general events, and event-specific knowledge, with the last of these levels consisting largely of sensory-perceptual information (Greenberg and Knowlton 2014, 293).

The use of hand-drawn sketches prompts interest and participation, which can help interactive stories become an educational tool. Interactive storytelling systems can be plotbased, character-based, or hybrid approaches. Hand-drawn sketches can be divided in two phases: i) a pre-processing phase and ii) a recognition phase, in which the drawings are identified in the segmented images and classified according to a set of previously specified objects. The combination of reality visualization with a sketch-based interaction can offer an environment for developing interactive narratives (De Lima, Feijo, Barbosa, Furtado, Ciarlini and Pozzer 2014, 34).

Jones $(2015,88)$ reports on workshops during which personal stories were assembled as biographies and narratives in an arts-based approach. Participants were encouraged to bring their past as a present to the workshop. In this field, researchers move into an interpretation of the visual as auto - ethnography/auto- biography to describe its author as a member of a culture at a specific time and place. Drawings can be a powerful means by which to recover the lived experiences and document personal moments from the lives of students (Jones 2015, 90).

Popovich (2006, 37) shares ideas on how in autobiographical drawings students use symbols to represent their career aspirations. The Looking Ahead to the Future composition encompasses the progressive step that looks at what has not yet happened but is shaped by past and present events. The students' drawings depict future symbols and written reflections describing a continuation of current interests and activities as well as a vision of future events in their lives.

\section{Theoretical framework}

This study is based on a constructive-developmental theory whereby knowledge and 
understanding are individually constructed by students, mostly by means of experiential learning. Underlying structures relating to knowledge and understanding are of prime importance. New knowledge is built into and added onto current structured units of knowledge, understanding and skill. This theory of learning falls under the umbrella of Cognitive Science, which investigates how people learn, remember and interact, with emphasis on mental processes. Prior knowledge plays a crucial part as an underlying structure (Pritchard 2005, 421).

The use of visual narratives as in the River of Life drawings in this study can be regarded as the recall and portrayal of prior experience from lifetime periods, general events, and eventspecific knowledge as part of an individual's autobiographical memory, an underlying structure of cognition.

Experiential learning in Art Education involves discovery as well as decision-making and the integration of information. Learning of this kind involves thinking, deciding and trying out, doing, reflecting and giving feedback. There is an active creation of new knowledge structures through personal experience. The process involves action, productivity through the process of discovery and creating occurs. Learners are active, take responsibility for their own learning and can relate and apply it to their own context (Gregory and Chapman 2002, 57).

\section{METHODOLOGY}

Welkener and Magolda (2014, 582-583) write about participant produced visual research in which autobiographical drawings become qualitative data from which patterns can be identified for coding into consistencies and meanings. Drawings provide a rich source that clarifies the frameworks students use to understand themselves, their social relations, and the world around them.

The methodology used for the assessment of first-year B.Ed. 1 students in Art Education can be regarded as a reflective study. Two assessment instruments were applied. The first assessment was designed to assist students to overcome their apprehension about mark-making (drawing) and with the second, consideration was given to whether assessments prepared students for a lifetime of learning.

For the drawing project, the literature on River of Life as visual narratives was adapted considering Roberts and Riley’s (2014, 292) account that visual research methods can express experiential knowledge that can be shared through visual media but not easily articulated through language. The contribution of drawing as a visual research strategy has an inclusive and extensive potential as a qualitative research method. 
The sample for this study consisted of the entire cohort of B.Ed. 1 Intermediate/Senior Phase students. Art Education is a compulsory subject for all of these students. Many first-year students enter their teacher training not having done any art since primary school. As part of the B.Ed. course they are required to produce a practical portfolio where they apply the art elements. For some students, this is a daunting task because they have very little confidence in their own creative ability. As a strategy to overcome their initial fear of drawing, a River of Life (Fisher and White 2015) exercise was introduced to set off their practical work.

Students were provided with an oblong $(400 \times 120 \mathrm{~mm})$ cartridge paper. As an introduction to this project, students had to reflect on five recent moments in their lives that had motivated them to pursue teaching as a career. They were asked to write these moments down in short sentences on the cartridge paper. Students were cautioned them not to reveal events or incidents that could evoke negative emotional responses or that could possibly be traumatic to disclose. However, they were reassured that nothing personal would be revealed to anybody.

After all the students recorded the five motivational incidents, The River of Life drawing technique was introduced, inspiring them to think of their lives as a river flowing. They were instructed to use line drawings to record the meaningful events and turning points in their life stories that they have written down. The river could take bends, and turns, cover rapids, rocks, obstacles or have waterfalls. It could split and come together again; there could be bridges crossing it or fallen trees and boulders along the course. Reflection with the use of the art element line was encouraged. A brief demonstration of the various qualities of line, namely soft, light, curved, strong and zigzag followed. Students were led to make use of interesting line work. Stereotypical symbols such as heart (love) and crosses (Christianity) were discouraged and the use of fresh, innovative symbols, signs and depictions that could 'describe' their journey towards teacher education were encouraged.

For the second assessment instrument, which formed part of this research, the focus was on the visual literacy component of their first-year Art Education course. In an attempt to improve their lack of knowledge on South African art and artists, students had to come to class with prepared notes on a list of topics and using that, had to design a flowchart as if in preparation for a slide show of a particular component of the work, something that they would need to know how to prepare as a teacher. Prior to this session there was an open-book Respondus test on Blackboard that also encouraged them to familiarise themselves with the content and knowledge they would need for the preparation of the concept maps.

A topic from the list they were provided earlier to prepare for the assessment session, was allocated to each student randomly like as they reported for the session, so nobody knew 
beforehand what component of the work would be assigned to them for the concept map assessment. This encouraged all of them to prepare all the topics on the list.

\section{ETHICS}

Clearance to conduct the research was obtained from the Faculty Ethics Committee and informed consent forms were signed by all the students who were willing participants in the study. There was an undertaking to treat the data with confidentiality and that no names would be published.

\section{DATA}

\section{River of Life drawings}

Some examples of the end results of the River of Life drawings were analysed as a possible reliable instrument for assessment of the practical application of the art elements by B.Ed. I students. The drawings were preceded by a reflective, introspective, preparatory, mindful and private conversation after which students had to write down the five moments in their lives that had led them to choosing teaching as a career. After giving them sufficient quiet time to really think, the five moments were written in single sentences. This was followed by guidance into a line-making exercise during which the students were to depict these important moments like a river flowing; sometimes smoothly, often overcoming obstacles, rocks and boulders, encountering rapids, widening and over precipices. This was done on oblong pieces of cartridge paper, using soft pencils to draw free and spontaneous, but thoughtfully controlled lines. Students were drawing without realising that they were making art.

Figures 1 and 2 are examples of the River of Life drawings of the first-year group.

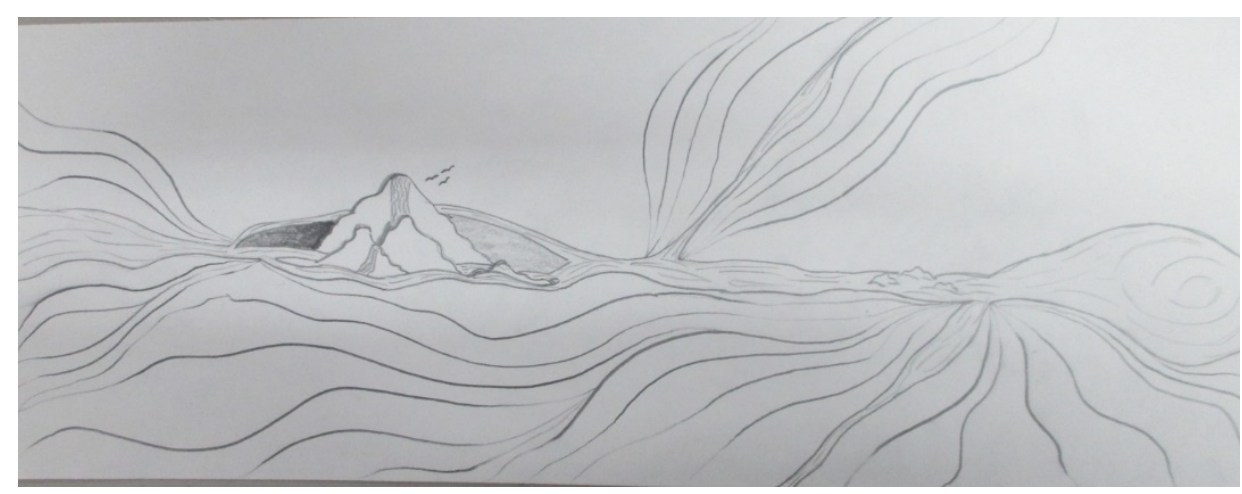

Figure 1: River of Life drawing 


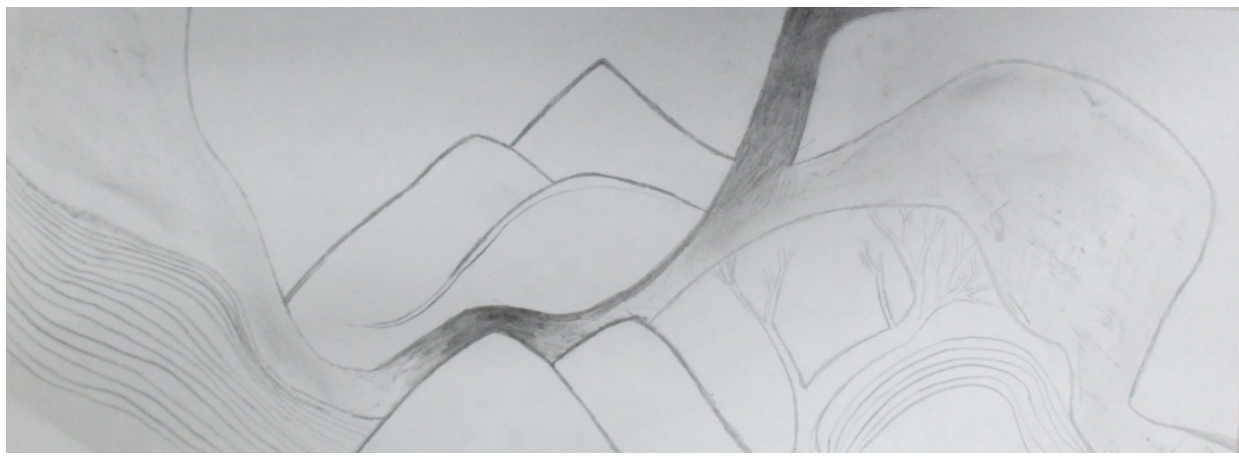

Figure 2: River of Life drawing

During the following session, each student selected an interesting section from the drawing to enlarge, like a blow-up, on an oblong grey sugar paper, this time drawing in white pastel. These enlargements (Figure 3) were used as surfaces for applying a colour mixing exercise. First-year students were applying the art elements in a calm and natural manner, without any realistic depiction expected from them. Due to the fact that their own personal course of life stories, as depicted in the River of Life drawings were the points of departure, they remained focussed while exercising and applying media that they could utilize in their teaching practice once they were teachers at schools.

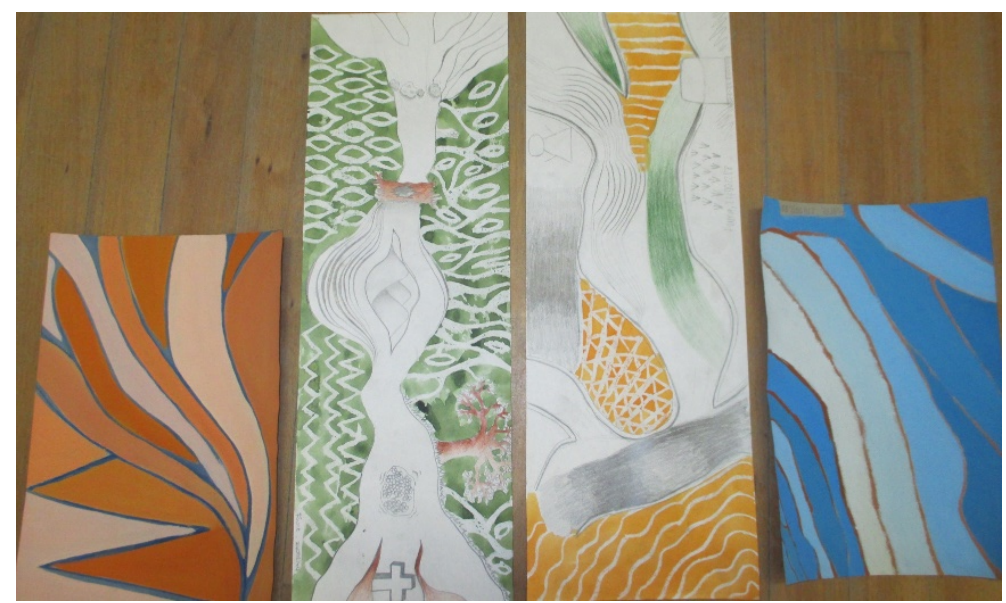

Figure 3: Examples of the application of the art elements in mixed media

\section{Theoretical work}

A further source of data was obtained from the results of a Respondus test on Blackboard that was administered as an open-book opportunity with the aim to familiarise the students with the study material in their textbooks. By doing this test, they obtained preparatory information for the assessment task which followed. The assessment culminated in the design of the concept maps that formed the basis of PowerPoint slide-shows which could be used in their visual 
literacy teaching practice.

Results of the concept map designs (Figure 4) as part of the theory assessment, were analysed to ascertain whether it has been a reliable tool for this particular component of their course, namely, whether students could source and apply knowledge about art and artists of South Africa.
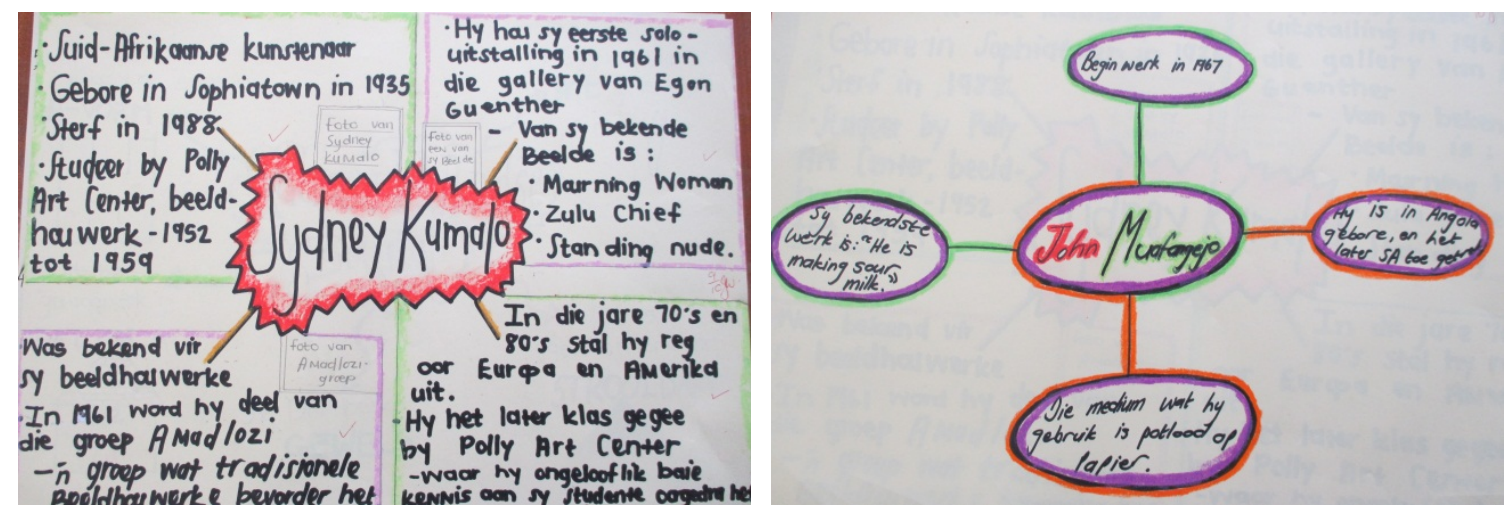

Figure 4: Concept map designs

\section{DISCUSSION OF THE DATA}

\section{River of Life drawings}

The first-year students were asked to contemplate the five directives in their lives that had led them to choosing teaching as a career. The reflective process culminated into their River of Life line-making whilst they employed the art elements, unknowingly making art. More elements were added to the initial drawings, first in light and dark shading and then the application of various media such as wax resist and a colour mixing exercise. In the past, to draw and make art, was for most first-year students, who have not done art since pre-school, a daunting experience, but the River of Life experience reduced the fear of drawing in a subtle and natural way and they participated without feeling threatened. There was a sense of confidence and wellbeing evident in all the groups. All first-years in produced projects with evident aesthetic sensibility, imagination and creativity and as such it could be used for their formative assessment mark.

\section{Theoretical work}

After completing the Respondus test on Blackboard in their own time, having engaged with the learning material in the textbook and other resources, all the first-year students came to class prepared for the sequential assessment opportunity. They were not anxious, because they were 
informed that it was not going to be a test, but an assessment opportunity. Students formed communities of practice, as they shared information and assisted one another in completing the concept maps. The entire group participated with sustained enthusiasm. The main purpose was to provide them with the means to access information on South African art and artists in future. There was a busy hum and great excitement in the classroom as they imparted information and applied the newly acquired information while they were searching additional information on the topics using Google on their smartphones or laptops.

\section{CONCLUSION}

The art subjects are often regarded as the add-ons or 'smaller' and unimportant subjects by undergraduate education students. First-years entering their teacher training come from schools with very little regard for or knowledge of Art Education. This often leads to an attitude of carelessness or lack of interest because they don't consider the arts as 'important' as some of their other subjects. However, due to the fact that it is a compulsory, credit-bearing subject of their first-year studies, there has to be some form of reliable and valid assessment.

Assessments such as the River of Life 'drawings' and the concept maps are valuable in helping first-year students to overcome their initial apprehension about mark-making, whilst it introduces them to reflective exercise. The concept maps preceded by an on-line Respondus test on Blackboard made assessments fun for contemporary students and the study material became less of a daunting task. Furthermore, the fact that students were required to source the knowledge required for the assessment task without any prior lecturing, made them responsible for their own learning. Therefore, the forms of assessment in this study can be regarded as sustainable assessment, as the learning processes opened the possibilities of lifelong learning.

The concept maps that were used for the groundwork of a PowerPoint slide show, prepares them for work that will be expected from them during teaching practice at schools. What they learnt and how they acquired that knowledge is applicable for their future careers. It can be valued as a practical, hands-on formative assessment that will lead to lifelong learning. Assessment which focusses on the learning process, provide opportunities other than traditional studying and writing tests, which often only measures rote learning.

\section{RECOMMENDATIONS}

\section{Practical portfolios for Art Education}

Fresh and innovative formative assessment instruments that deepen the understanding of art 
concepts and skills of first-year students can help them overcome their initial fear of markmaking due to a lack of confidence in their own drawing ability. Divergent assessment tasks that are conducive to student development, can be beneficial, especially to first-years, who often lack confidence and are mostly unfamiliar with reflection and self-monitoring.

First-year students can be guided to produce unique artworks through the application of the art elements, by means of thoughtful and reflective processes.

\section{Theoretical work}

Visual literacy studies explore the historical, cultural, and critical context from which visual art content derives. Ideas suitable for use in primary schools can be developed from themes. Students ought to receive opportunities to organize their knowledge and collect information from online resources, observations, library research and reading independently. This information should be applied in creating concept maps, which can eventually lead to quality slide shows that teachers can use in their visual literacy teaching during teaching practice and eventually in their own classrooms.

Projects such as have been discussed in this article provide formative assessment tools that lead to lifelong learning which encourages student development and self-regulation, following suggestions by Yorke (2003, 480). Substituting traditional assessments with instruments that focus on the learning process, can result in 'sustainable assessment' (Boud 2000,19), which is likely to continue after the assessment period and into their future careers.

\section{REFERENCES}

Andrade, H., J. Hefferen and M. Palma. 2014. Formative assessment in the visual arts. Art Education 67(1): 34-40. http://web.ebscohost.com/ (accessed 25 November 2015).

Black, P., C. Harrison, C. Lee, B. Marshall and D. William. 2006. Assessment for learning. Putting it into practice. England: McGraw-Hill.

Bolton, H. 2006. Pedagogy, subjectivity and mapping judgment of art, a weakly structured field of knowledge. Journal of Education 40: 51-78. http://web.ebscohost.com/ (accessed 26 September 2011).

Boud, D. and N. Falchikov. (Eds.). 2007. Rethinking assessment in higher education: Learning for the longer term. London: Routledge.

Boud, D. 2000. Sustainable assessment: Rethinking assessment for the learning society. Studies in Continuing Education 22(2): 151-167. http://web.ebscohost.com/ (accessed 29 October 2015).

Brandt, R. 1987. On assessment in the arts: A conversation with Howard Gardner. Educational Leadership: 30-34. http://web.ebscohost.com/ (accessed 29 October 2015).

Cohen, R. 2015. From child art to visual language of youth: New models and tools for assessment of learning and creation in Art Education. Studies in Art Education 56(4): 382-385.

De Lima, E. S., B. Feijo, S. D. J. Barbosa, A. L. Furtado, A. E. M. Ciarlini and C. T. Pozzer. 2014. Draw your own story: Paper and pencil interactive storytelling. Entertainment computing. Elsevier B.V. 
http://dx.doi.org/10.1016/j.entcom (accessed 10 January 2016).

Dreyer, J. (Ed.). 2014. The educator as assessor. Pretoria: Van Schaik.

Fisher, C. and N. White. 2015. River of Life. http://ciatcapacity.cgiar.org/en/2011/09/river-of-life/ (accessed 5 December 2015).

Greenberg, D. L. and B. J. Knowlton. 2014. The role of visual imagery in autobiographical memory. Memory and Cognition 42: 922-934. http://web.ebscohost.com/ (accessed 20 October 2015).

Gregory, G. H. and C. Chapman. 2002. Differentiated instructional strategies. One size doesn't fit all. Thousand Oaks: Corwin.

Jones, K. 2015. A Report on an arts-led, emotive experiment in interviewing and storytelling. The Qualitative Report 20(2) Article 6: 86-92. http://www.nova.edu/ssss/QR/QR20/2/jones6.pdf (accessed 10 January 2016).

Leong, S. and X. Qui. 2013. Designing a creativity and assessment scale for arts education. Educational Pshycology: An International Journal of Experimental Educational Psychology 33(5): 596-615. http://www.tandfonline.com/loi/cedp20 (accessed 23 February 2015).

Maki, P. L. 2007. Assessing for learning. Building a sustainable commitment across the institution. USA: Stylus.

Morris, R. J. 2015. Draw my life: Creative reflection through stick figure storytelling. In iConference Proceedings: 1-3. http://googlescholar (accessed 5 December 2015).

Popovich, K. 2006. Designing and implementing exemplary content, curriculum and assessment in Art Education. Art Education November: 33-39. http://web.ebscohost.com/ (accessed 5 December 2015).

Pritchard, A. 2005. Ways of learning. London: David Fulton.

Quinn, L. 2015. In Assessment in higher education: Reframing traditional understandings and practices, ed. S. Clarence, L. Quinn and J. Vorster, 02-05. Rhodes: CHERTL.

Roberts, A. and H. Riley. 2014. Drawing and emerging research: The acquisition of experiential knowledge through drawing as a methodological strategy Arts and Humanities in Higher Education. An International Journal of Theory, Research and Practice 13(3): 292-302. (accessed 30 July 2014).

Stokrocki, M. 2005. Reconsidering everyday assessment in the art classroom: Ceramics and science. Arts Education Policy Review 107: 15-21. http://web.ebscohost.com/ (accessed 25 June 2014).

Welkener, M. M. and M. B. B. Magolda. 2014. Better understanding of students' self-authorship via self-portraits. Journal of College Student Development September 55(6): 580-585. http://web.ebscohost.com/ (accessed 5 December 2015).

Yorke, M. 2003. Formative assessment in higher education: Moves towards theory and the enhancement of pedagogic practice. Higher Education 45: 477-501. http://web.ebscohost.com/ (accessed 5 December 2015). 